\title{
Die bepaling van intrasellulêre vry kalsium in die neutrofiel met die fluoressente kalsiumindikators, fura-2 en fura-PE3
}

\author{
A.M. Koorts ${ }^{\star}$, M. Viljoen en M.C. Kruger \\ Departement Fisiologie, Fakulteit Genecskunde, Universiteit van Pretoria, Posbus 2034, Pretoria, 0001 \\ E-posadres: akoorts@medic.up.ac.za
}

Ontvang 28 Augustus 2000; aanvaar 13 Oktober 2000

\section{UITTREKSEL}

Verskeie fuoressente kalsiumindikators is beskikbaar vir die bepaling van die konsentrasie van intrasellulêre vry kalsium. Die bekendste hiervan is fura-2. Die gebruik van onder andere fura-2 vir die bepaling van intrasellulêre vry kalsium kan verskeie probleme inhou. Een hiervan is die bepaling van verhoogde intrasellulêre vry kalsium a.g.v. die uitlek van die indikator na die ekstrasellulêre medium. Fura-PE3. 'n fuoressente kalsiumindikator verwant aan fura-2, is vervolgens gesintetiseer: Daar word voorgehou dat fura-PE3 nie noemenswaardig uillek na die ekstrasellulêre medium nie. In die studie word aangetoon dat beide fura-2 en fura-PE3 teen ongeveer dieselfde tempo uillek na die ekstrasellulêre medium in die neutrofiel en dat die bepaling van intrasellulêre vry kalsium met fura-PE3 dus geen werklike voordele bo fura-2 inhou nie. Daar word vervolgens aangetoon dat die herhaalbaarheid van die bepaling van intrasellulêre vry kalsium deur die fluoressente kalsiumindikators aanvaarbaar is indien die tydsverloop tussen die laai en wasstappe en die begin van die fluoressensiebepalings kort gehou word deur slegs een monster op 'n slag te doen, en dat die metode sensitief genoeg blyk te wees om variasie in basale intrasellulêre vry kalsium waar te neem.

\begin{abstract}
Intracellular free calcium determination in neutrophils with the fluorescent calcium indicators, fura-2 and fura-PE3 A large number of fluorescent calcium indicators are available for the determination of intracellular fiee calcium concentrations. The best known of these is fura-2. However, the employment of fura-2, amongst others, for the determination of intracellular free calcium is not problem-free. One of the problems encountered is the determination of an elevated intracellular free calcium concentration due to the leakage of the indicator to the extracellular medium. Fura-PE3, a fuorescent calcium indicator related to fura-2, was synthesised to overcome this problem. It is claimed that fura-PE3 shows no significant leakage to the extracellular medium. This study indicates that since both fura-2 and fura-PE3 leak from the neutrophil to the extracellular medium at more or less the same rate, the determination of neutrophil intracellular free calcium with fura-PE3 is not superior to that with fura-2. Subsequently it is indicated that the reproducibility of intracellular calcium determination with the fluorescent calcium indicators is acceptable as long as the time delay between the loading and the washing of the neutrophils and the start of the fluorescence determination is kept to a minimum by determining only one sample at a time. Furthermore, it appears that the method is sensitive enough to be able to indicate a change in basal intracellular free calcium.
\end{abstract}

\section{INLEIDING}

Die bepaling van intrasellulêre vry kalsium met dic fluoressente kalsiumindikators het gelei tot ' $n$ magdom ondersoeke na kalsium se rol in verskeie fisiologiese en patologiese prosesse. Die ontwikkeling van die fluoressente kalsiumindikators vir die bepaling van intrasellulêre vry kalsium het grootliks hiertoe bygedra. Dic fluoressente kalsiumindikators kan onder andere as esterderivate oor dic selmembraan beweeg en dus is ekstreme prosedures nie nodig om die indikator binne die sel te kry nie. Wannecr die esterkalsiumindikatorderivaat in die sitoplasma beland, sal esterases teenwoordig in die sitoplasma die esterverbindings breek.' Gevolglik word die penta-anioonindikator gevorm wat dic beskikbare vrykalsium-ione in die sitoplasma kan bind. Die verhouding van dic fluoressensic van die kalsiumindikator gebonde aan kalsium tot die verhouding van die fluoressensic van dic vrykalsiumindikator verteenwoordig die konsentrasie van die intrasellulêre vry kalsium. ${ }^{2}$ Verskeie fluoressente kalsiumindikators is beskikbaar. ${ }^{2}$ Die bekendste hiervan is fura-2. Alhoewel die bepaling van intrasellulêre vry kalsium met behulp van fura-
2 aanvaarbare resultate in verskeic seltipes oplewer, is daar aanduidings dat dic uitlek van dic indikator na dic ekstrasellulêre medium en kompartementalisering in intrasellulêre organelle aanleiding mag gee tot afwykings in die waardes vir die konsentrasie van intrasellulêre vry kalsium. ' $n$ Verbeterde fluoressente kalsiumindikator is onlangs beskikbaar gestel om hierdie probleme te omseil. Hicrdic kalsiumindikator, fura-PE3, verwant aan fura-2, was gesintetiseer om uitlek na die ekstrasellulêre medium en kompartementalisering in intrasellulêre organelle van die indikator te voorkom. ${ }^{3}$ Die bepaling van intrasellulêre vry kalsium in die neutrofiel is tot onlangs slegs m.b.v. fura-2 bepaal. ${ }^{4.5}$. Daar is tans geen gepubliseerde resultate van dic bepaling van intrasellulêre vry kalsium in die neutrofiel met behulp van fura-PE3 beskikbaar nic. Hierdic studie stel ondersock in na die gebruik van fura-PE3 in die bepaling van intrasellulêre vry kalsium in neutrofiele en die vergelyking hiervan met die gebruik van fura-2. Beide hierdie fluoressente kalsiumindikators is geskik vir die bepaling van intrasellulêre vry kalsium met 'n Kd vir fura-2 van $224 \mathrm{nM}$ en 'n $\mathrm{Kd}$ vir fura-PE3 van $250 \mathrm{nM}^{3}$ 


\section{MATERIALE EN METODES}

Vir die bepaling van intrasellulêre vry kalsium is dit nodig om neutrofiele te isoleer sonder om enige funksionele skade wat mag lei tot 'n verandering in intrasellulêre vry kalsium te veroorsaak.

\section{Isolering van neutrofiele}

Polimorfonukleêre leukosicte is soos volg vanuit $7 \mathrm{ml}$ volbloed met "suur-sitraat-dekstrose" ( $A C D$ ) (Becton Dickenson Vacutainer sisteme) as antikoagulant geïsolecr. Ses $\mathrm{ml} \Lambda \mathrm{CD}$ volbloed is bo-op ' $\mathrm{n}$ volume van $3 \mathrm{~m} /$ ficoll-hypaque (Histopaque - 1077 Sigma Kat. No. $1077-1$ ) in 'n koniese buis $(15 \mathrm{ml})$ gepipeteer en daarna teen $800 \mathrm{Xg}$ by $12^{\circ} \mathrm{C}$ vir 25 minute gesentrifugecr. Dic polimorfonukleĉre leukosiete (PMNL's) vorm ' $n$ wit laag bo-op die massa rooibloedselle in dic onderpunt van dic buis. Dic supernatant is verwyder en die rooiblocdselle met ' $n$ ammoniumchloricdoplossing geliseer $\left(155 \mathrm{mM} \mathrm{NH}_{4} \mathrm{Cl}\right.$, $12 \mathrm{mM} \mathrm{NaHCO}, 0.25 \mathrm{mM}$ EDTA). Dic PMNL's is hierna cen maal met $4 \mathrm{ml}$ Hepes-gebufferde Hanks-oplossing gewas (Highveld Biological PTY.LTD. Kat. No. CN 2027-3, KCl, $\mathrm{KH}_{2} \mathrm{PO}_{4}$, Glukose, $\mathrm{MgSO}_{4} .7 \mathrm{H}_{2} \mathrm{O}$, Hepes, $\mathrm{NaHCO}_{3}, \mathrm{CaCl}_{2}, \mathrm{pH}$ $7.425^{\circ} \mathrm{C}$ ) en finaal in $2 \mathrm{ml}$ van dic buffer gesuspendecr. Hicrdic is ' $\mathrm{n}$ aanpassing van die metode van Böyum.'

\section{Bepaling van intrasellulêre vry kalsium $\left(\left[\mathrm{Ca}^{2+}\right]_{i}\right)$ in die neutrofiel}

Bepaling van [ $\mathrm{Ca} 2+] \mathrm{i}$ in die neutrofiel is soos volg met beide die fluoressente kalsiumindikators, fura-2 (fura-2/AM Sigma Kat. No. F 0888) en fura-PE3 (fura-PE3/AM Sigma Kat. No. F 0918 ) uitgevoer. Die geïsolecrde PMNL's is in 'n $0.25 \%$-BS $\Lambda$ / Hanks-buffer by ' $\mathrm{n}$ konsentrasic van $2 \times 10^{6}$ selle/ml gehersuspendeer en met óf fura-2/AM (finale konsentrasic $2 \mu \mathrm{M}$ ) óf fura-PE3/AM (finale konsentrasic $2 \mu \mathrm{M}$ ) vir 30 minute by $37^{\circ} \mathrm{C}$ in ' $n$ bewegende waterbad en vir' ' $n$ addisionele 30 minute by kamertemperatuur gelaai. Die neutrofielsuspensic met dic kalsiumindikators is gedurende hierdie laaiperiode teen lig beskerm. Hierna is die neutrofielsuspensie teen $350 \mathrm{Xg}$ by $12{ }^{\circ} \mathrm{C}$ vir 10 minute gesentrifugeer en die supernatant verwyder om van die oortollige indikator ontslac te raak. Die neutrofiele is daarna twee maal met 'n $0.25 \%$-BSA/Hanks-buffer gewas en finaal by ' $\mathrm{n}$ konsentrasic van $2 \times 10^{6} \mathrm{selle} / \mathrm{ml}$ gehersuspendeer. $900 \mu l$ van hicrdic oplossing is in die spektrofluorometerkuvet (Perkin Elmer LS 50B spektrofotometer) geplaas by $37^{\circ} \mathrm{C}$, en nog $1100 \mu \mathrm{l}$ van dic $0.25 \%$-BSA/Hanks-buffer bygevocg. Nadat dic vlakke van basaal intrascllulêre vry kalsium bepaal is, is formicl-metiel-leusiel-feniclalanien (fMLP Sigma Kat. No. F 3506) met finale konsentrasic van $1 \mu \mathrm{M}$ bygevoeg om 'n kalsium respons uit te lok. Vir dic kalibrering an dic einde van dic eksperiment is $100 \mu \mathrm{l}$ van 'n TritonX-100-oplossing ( $1 \% \mathrm{v} / \mathrm{v})$ bygevoeg om die selle te lisecr. Bepaling van fluoressensic by 'n maksimum kalsium-konsentrasic het gevolg. Ten einde dic fluoressensic vir minimum kalsium-konsentrasie te bepaal, is $100 \mu$ l van 'n $0.5 \mathrm{M}$ EGTA $3 \mathrm{M}$ Tris $\mathrm{pH} 8.7$ by $25^{\circ} \mathrm{C}$ bygevoeg. Om die konsentrasic van intrasellulêre vry kalsium te bereken, is dic Grynkicwicz-vergelyking opgelos. ${ }^{8}$

Bepaling van die uitlek van die indikators na die ekstrasellulêre medium

Dic opeenvolgende stappe vir die bepaling van dic uitlek van die indikators sluit in a) isolering van die neutrofiele; b) laai van die indikators of fura-2 of fura-PE3; c) was van dic neutrofielsuspensic om van dic oortollige indikators in dic medium ontslac te raak (al die stappe tot dusver is beskryf in die vorige paragraaf); d) inkubasic van dic neutroficlsuspensie; c) bepaling van die fluoressensiewaardes; $f$ ) byvoeging van dic nikkelchloricdoplossing; g) bepaling van dic fluoressensicwaardes. Die inkubasietye en -temperature vir stap d was soos volg - twee minute op ys vir ' $n$ alikwot van die neutrofielsuspensic en vir 'n tweede alikwot van dieselfde neutrofielsuspensic 50 minute op ys. Met die einde van die onderskeic inkubasieperiodes is dic basaalvlak-fluoressensic bepaal, waarna $20 \mu l$ van ' $n$ nikkelchloriedoplossing (finale nikkelchloriedkonsentrasie $2 \mathrm{mM}$ - Sigma Kat. No. N 6136) bygevocg is. Nikkel is gebruik om die fluoressensic van die kalsiumindikators wat teenwoordig is in die ekstrasellulêre medium te blus. ${ }^{2}$ Die afname in die verhouding tussen fluoressensic by $340 \mathrm{~nm}$ en dic fluoressensic by $380 \mathrm{~nm}$ was ' $n$ aanduiding van die uitlek van dic indikators na die ekstrasellulêre medium, wat plaasgevind het gedurende die inkubasieperiode. Hierdie prosedure is vir beide die indikators, fura-2 en fura-PE3 uitgevoer. Vervolgens is dic verhoging in die konsentrasie van intrasellulêre vry kalsium bepaal met dic uitlek van dic kalsiumindikators.

Bepaling van die verhoging in die konsentrasie van intrasellulêre vry kalsium a.g.v. die uitlek van die indikators na die ekstrasellulêre medium

Met dic byvoeging van nikkelchloried is dit nie moontlik om die kalibreringstappe aan die einde van die eksperimentele prosedures uit te voer nic. Om die konsentrasic van intrasellulêre vry kalsium te kan bepaal wat verkeerdelik gemeet word a.g.v. die uitlek van die indikators na die ekstrasellulêre medium is ' $n$ parallelle stel eksperimente uitgevocr. Intrasellulêre vry kalsium is na ' $n$ inkubasieperiode van twee minute vir 'n alikwot van die neutrofielsuspensie, en vir 'n tweede alikwot van dieselfde neutrofielsuspensie na 'n inkubasieperiode van 50 minute bepaal.

Ondersoek na die herhaalbaarheid en sensitiwiteit van die bepaling van intrasellulêre vry kalsium in die neutrofiel Om die herhaalbaarheid van die bepaling van intrasellulêre vry kalsium in die neutrofiel met behulp van die fluoressente kalsiumindikators te ondersoek, is die volgende uitgevoer: Eerstens is die intrasellulêre vry kalsium vir dieselfde persoon se neutrofiele op verskillende geleenthede bepaal. Tweedens is die intrasellulêre vry kalsium vir verskillende persone se neutrofiele op verskillende geleenthede bepaal. Om dic sensitiwiteit van die metode vir dic bepaling van intrasellulêre vry kalsium in die neutrofiel met behulp van die fluoressente kalsiumindikators te ondersock, is bepalings in verskeic pasiënte gedoen.

\section{RESULTATE}

Figuur I en figuur 2 stel dic afname voor in die waarde vir die verhouding tussen die fluoressensic vir die $340 \mathrm{~nm}$-golflengte en die 380 nm-golflengte vir onderskeidelik fura-2 en fura-PE3 met die byvoeging van nikkelchloricd na ' $n$ inkubasieperiode van twee minute op ys. Figuur 3 en figuur 4 stel dic afname voor in die waarde vir die verhouding tussen die fluoressensic vir die $340 \mathrm{~nm}$-golflengtc en die $380 \mathrm{~nm}$-golflengte vir onderskeidelik fura-2 en fura-PE3 met die byvocging van nikkelchloried na ' $n$ inkubasicperiode van 50 minute op ys. Tabel I bevat 'n opsomming van hierdie waardes en die afname in hicrdic waardes met dic toediening van nikkelchloricd. Vir fura-2 is ' $n$ afname van 1.26 na 1.21 met nikkelchloriedtoediening na die tweeminute-inkubasieperiode gevind, terwyl vir fura-PE3 'n afname van 1.19 na 1.17 met nikkelchloriedtoediening vir dieselfde periode waargeneem is. Vir fura-2 is 'n afname van 1.36 na 1.26 met nikkelchloriedtoediening na die 50-minute-inkubasieperiode gevind, terwyl vir fura-PE3 'n 
afname van 1.26 na 1.17 met nikkelchloricdtoediening vir dieselfde periode waargeneem is. Beide dic indikators, fura-2 en fura-PE3 het dus na die ekstrasellulêre medium gelek. FuraPE3 se uitlekking was egter van kleiner omvang, veral met die tweeminute-inkubasieperiode. Figuur 5 stel dic skyn toename in intrasellulêre vry kalsium voor wat gemeet word a.g.v. die uitlek van dic fluoressente kalsiumindikator na dic ckstrasellulêre medium gedurende die 50-minute-inkubasieperiode. Die uitlek van dic kalsiumindikators vertecnwoordig 'n skynverhoging van $17 \mathrm{nM}$ in dic konsentrasic van dic intrasellulêre vry kalsium oor 'n 50-minute-inkubasieperiode. Die skyntoename in intrasellulêre vry kalsium soos bepaal vir fura-PE3 na ' $n$ inkubasieperiode van twee minute verteenwoordig $2 \mathrm{nM}$, en is weglaatbaar klein.

Die hieropvolgende bepalings vir die herhaalbaarheid en sensitiwiteit van die tegnick is gedoen met die kalsiumindikator, fura-PE3 en vir 'n inkubasieperiode van twee minute. Figuur 6 stel die bepalings van intrasellulêre vry kalsium voor soos verkry vir dieselfde persoon se neutrofiele oor 'n tydperk van twee weke $(n=4)$. Die waardes vir basaal intrasellulêre vry kalsium was soos volg: $45 \mathrm{nM}, 54 \mathrm{nM}, 52 \mathrm{nM}, 45 \mathrm{nM}$. Figuur 7 stel intrasellulêre vry kalsium voor soos verkry vir ses verskillende persone se neutrofiele oor 'n tydperk van dric weke. Om verlengde inkubasieperiodes te verhoed en sodoende uitlekking tc minimalisecr, is slegs een bepaling per dag gedoen. Dic waardes vir basale intrasellulêre vry kalsium was soos volg:
$50 \mathrm{nM}, 52 \mathrm{nM}, 50 \mathrm{nM}, 52 \mathrm{nM}, 57 \mathrm{nM}, 53 \mathrm{nM}$. Dic volgende stap was om te bepaal of die metode wel sensiticf genoeg is om variasies in intrasellulêre vry kalsium te meet. Figuur 8 tot 11 stel die bepalings van intrascllulçre vry kalsium voor vir verskeic intensiewesorgpasiënte. Vir elk van dic pasiënte, bchalwe vir een weens komplikasies, is twee bepalings uitgevoer en word dit op dieselfde grafick voorgestel. Die twee bepalings per pasient is uitgevoer op stadia van die hospitalisering waarin daar duidelike aanduidings van ó verbetering óf agteruitgang in dic pasiënt se toestand waarnecmbaar was.

Tabel 1 Die fluoressensieverhoudingwaardes voor en na nikkelchloriedbyvoeging vir beide fura-2 en fura-PE3 soos bepaal na die 2-minute- en na die 50-minuteinkubasieperiodes

\begin{tabular}{|l|c|c|c|}
\hline Inkubasic tye & $\begin{array}{c}\text { Voor nikkel- } \\
\text { chloried- } \\
\text { toediening }\end{array}$ & $\begin{array}{c}\text { Na nikkel- } \\
\text { chloried- } \\
\text { toediening }\end{array}$ & Verskil \\
\hline Fura-2: 2 minute & 1,26 & 1,21 & 0,05 \\
\hline Fura-PE3: 2 minute & 1,19 & 1,17 & 0,02 \\
\hline Fura-2: 50 minute & 1,36 & 1,26 & 0,1 \\
\hline Fura-PE3: 50 minute & 1,26 & 1,17 & 0,09 \\
\hline
\end{tabular}

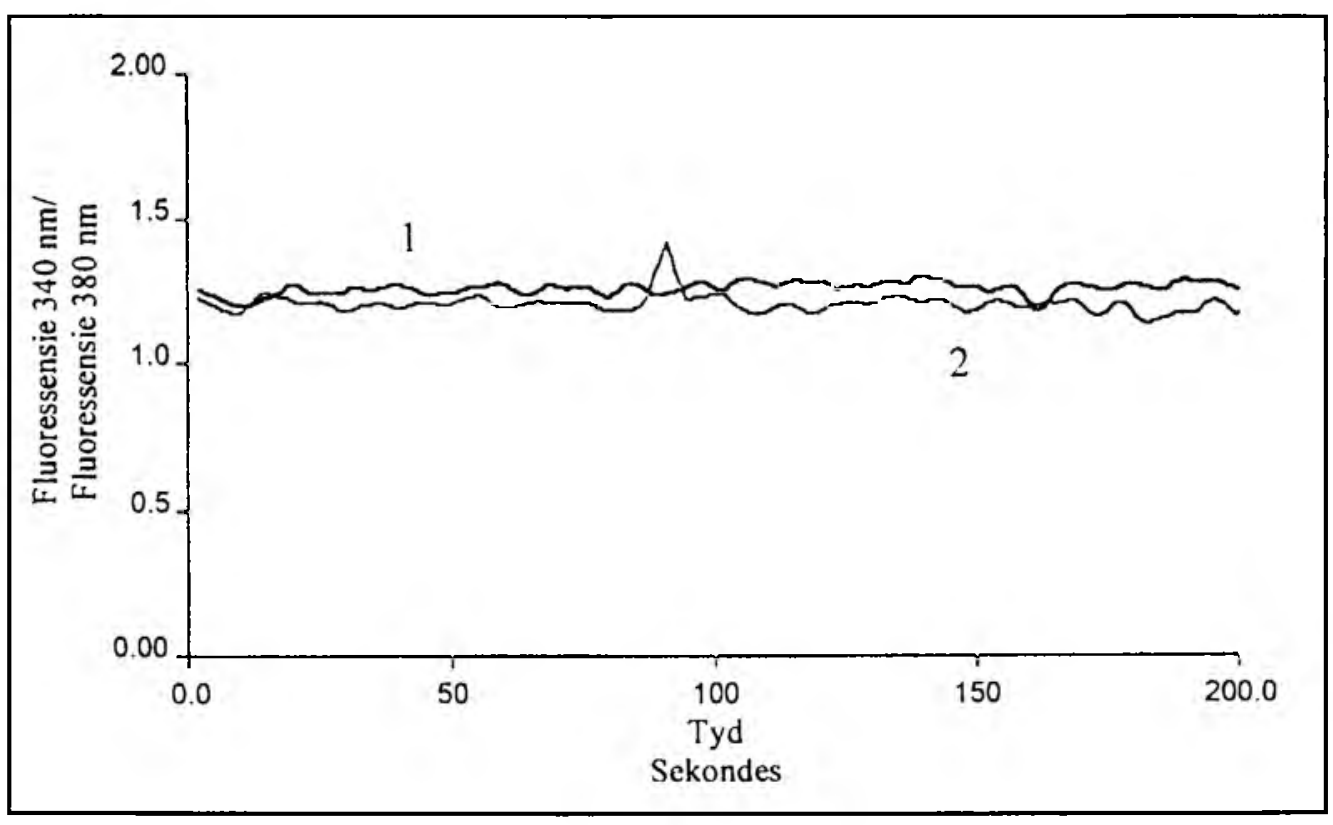

Figuur 1: Twee verhoudings fluoressensiegrafieke van fura-2 na 'n tweeminute-inkubasieperiode. Die eerste is bepaal voor die byvoeging van nikkelchloried en die tweede is bepaal na die byvoeging van nikkelchloried. Die grafieke toon 'n verlaging in die fluoressensieverhoudingwaardes van 1.26 na 1.21 aan. 


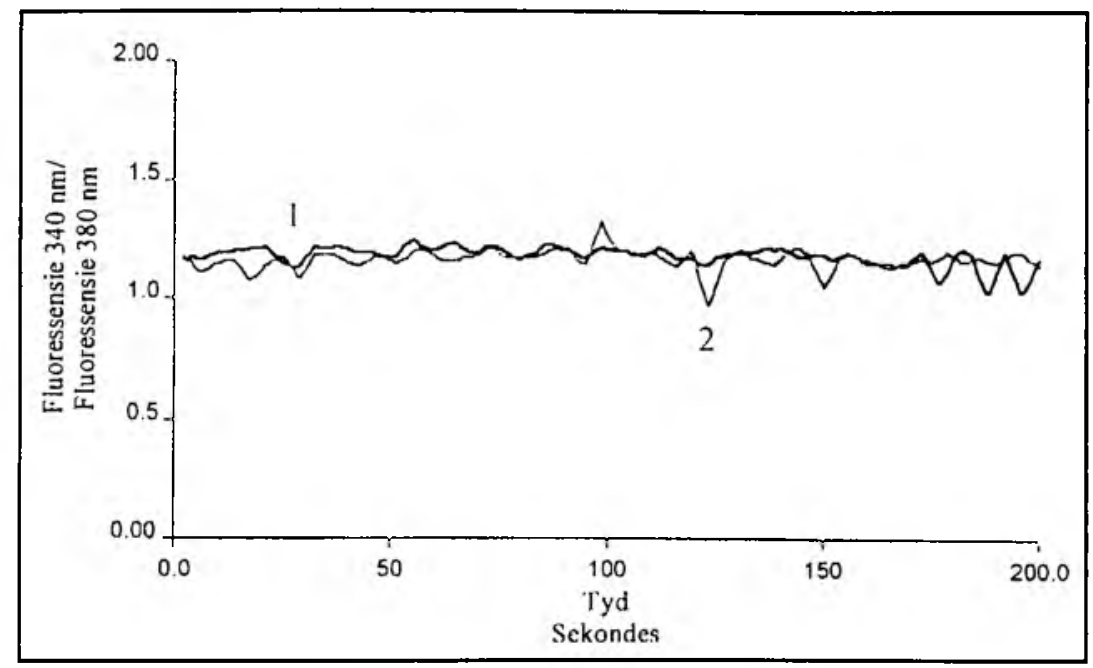

Figuur 2: Twee verhoudings fluoressensiegrafieke van firra-PE3 na 'n tweemimuteinkubasieperiode. Die eerste is bepaal voor die byvoeging van nikkelchloried en die tweede is bepaal na die byvoeging van nikkelchloried. Die grafieke toon 'n verlaging in die fluoressensieverhoudingwaardes van 1.19 na 1.17 aan.

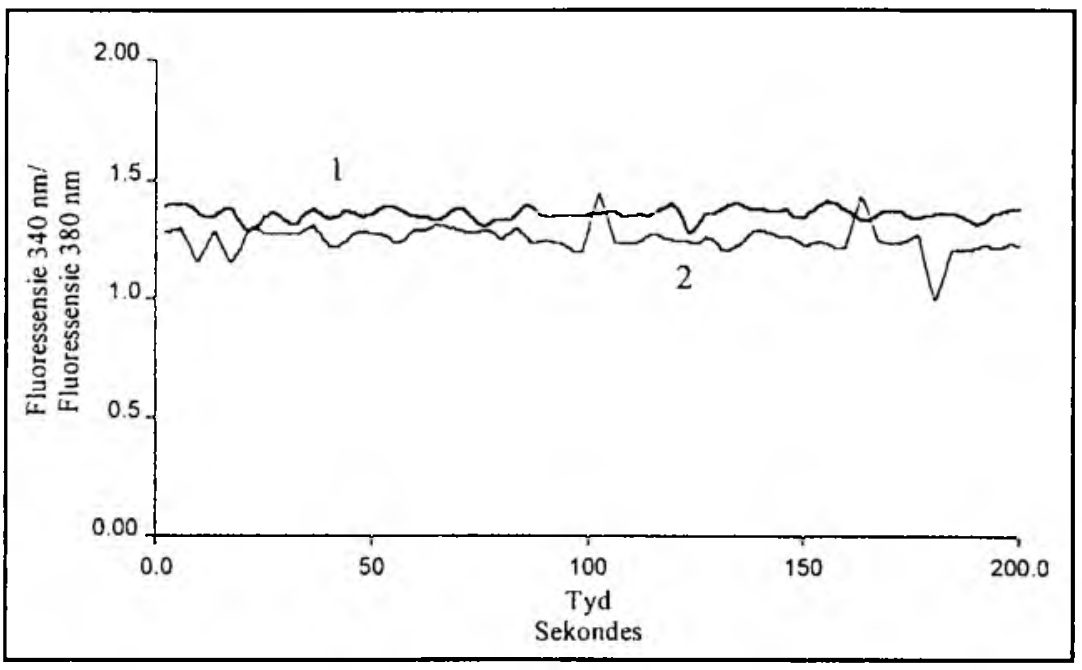

Figuur 3: Twee verhoudings fluoressensiegrafieke van fura-2 na 'n 50-minuteinkubasieperiode. Die eerste is bepal voor die byvoeging van nikkelchloried en die tweede is bepaal na die byvoeging van nikkelchloried. Die grafieke toon 'n verlaging in die fluoressensieverhoudingwardes van $1.36 \mathrm{na} 1.26 \mathrm{aan}$.

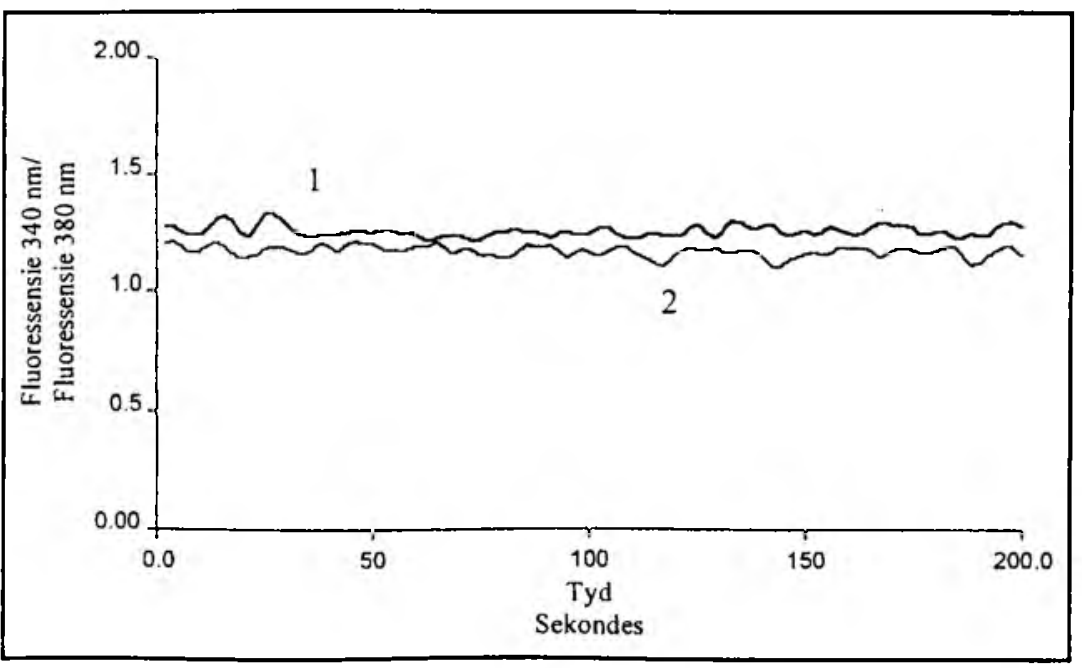

Figuur 4: Twee verhoudings fluoressensiegrafieke van fura-PE3 na 'n 50-mimuteinkubasieperiode. Die eerste is bepaal voor die byvoeging van nikkelchloried en die tweede is bepaal na die byvoeging van nikkelchloried. Die grafieke toon ' $n$ verlaging in die fluoressensiever houdingwardes van $1.26 \mathrm{na} 1.17 \mathrm{aan}$. 


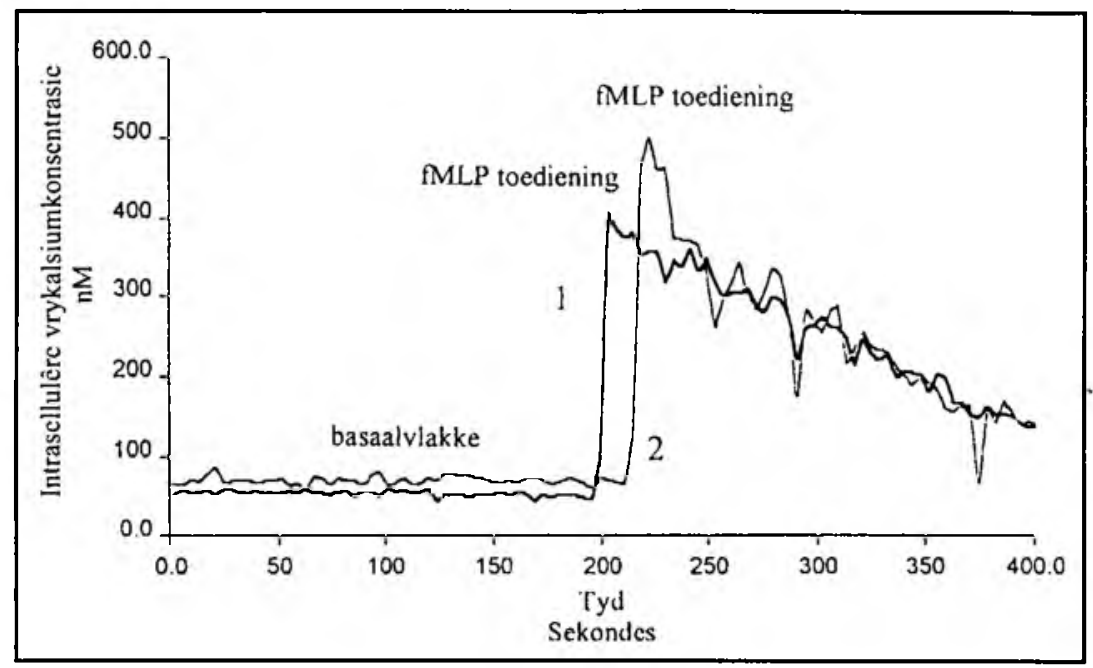

Figuur 5: Twee intrasellulêre vrykalsiumkonsentrasiegraficke. Die eerste grafiek verteenwoordig die intrasellulêre vrykalsiumkonsentrasie soos bepaal voor die begin van die 50-minute-inkubasieperiode en die tweede grafiek verteenwoordig die intrasellulêre vrykalsiumkonsentrasie soos bepaal aan die einde van die 50-minuteinkubasieperiode. 'n Toename in intrasellulêre vry kalsium van $17 n M$ word bepaal a.g.v. die uitlek van die indikator na die ekstrasellulêre medium gedurende die 50minute-inkubasieperiode.

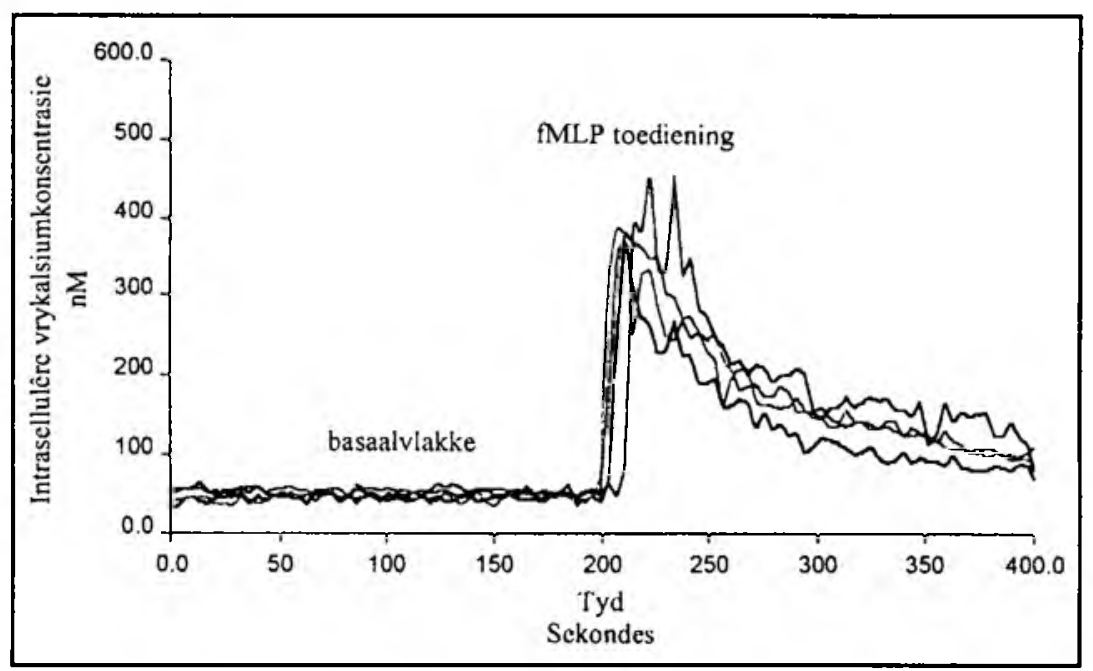

Figuur 6: Grafieke wat die inirasellulêre vrykalsiumkonsentrasies verteenwoordig soos bepaal vir dieselfde persoon oor 'n tydperk van twee weke.

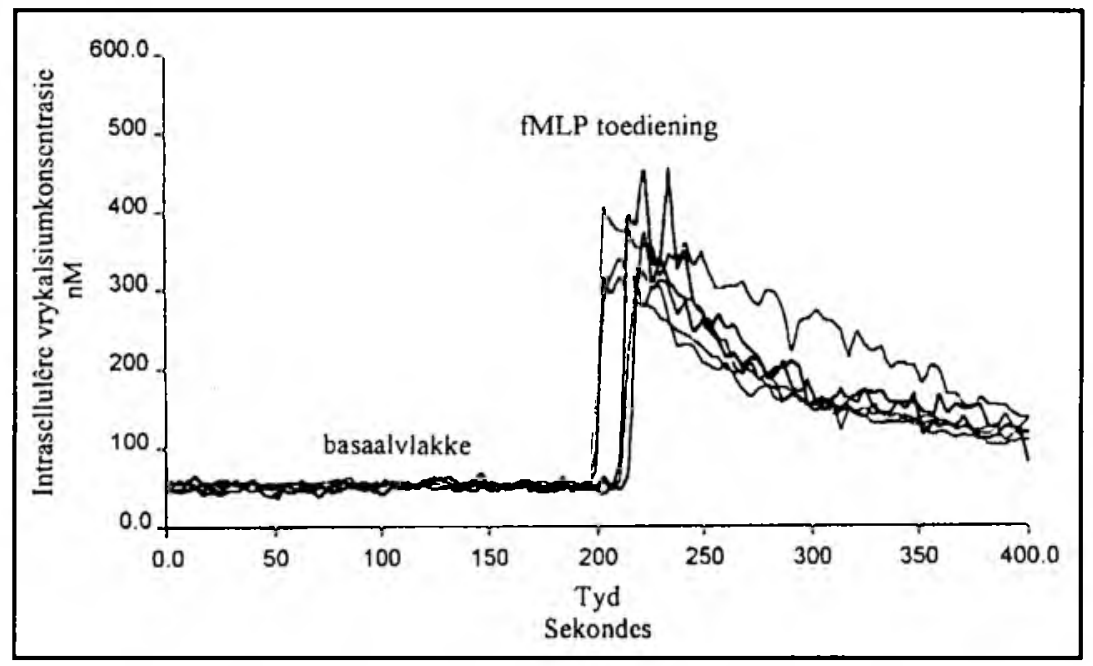

Figuur 7: Grafieke wat die intrasellulêre vrykalsiumkonsentrasies verteenwoordig soos bepaal vir verskillende persone oor 'n tydperk van drie weke. 
Figure 8 tot 11: Grafieke wat die intrasellulêre vrykalsiumkonsentrasies verteenwoordig soos bepaal vir vier pasiënte. Vir die pasiënte waarvoor intrasellulêre vrykalsiumbepalings twee keer tuitgevoer is, word 'n verandering in intrasellulêre vry kalsium wat gepaardgaan met ' $n$ verandering in die kliniese kondisie van die pasiënt aangetoon.

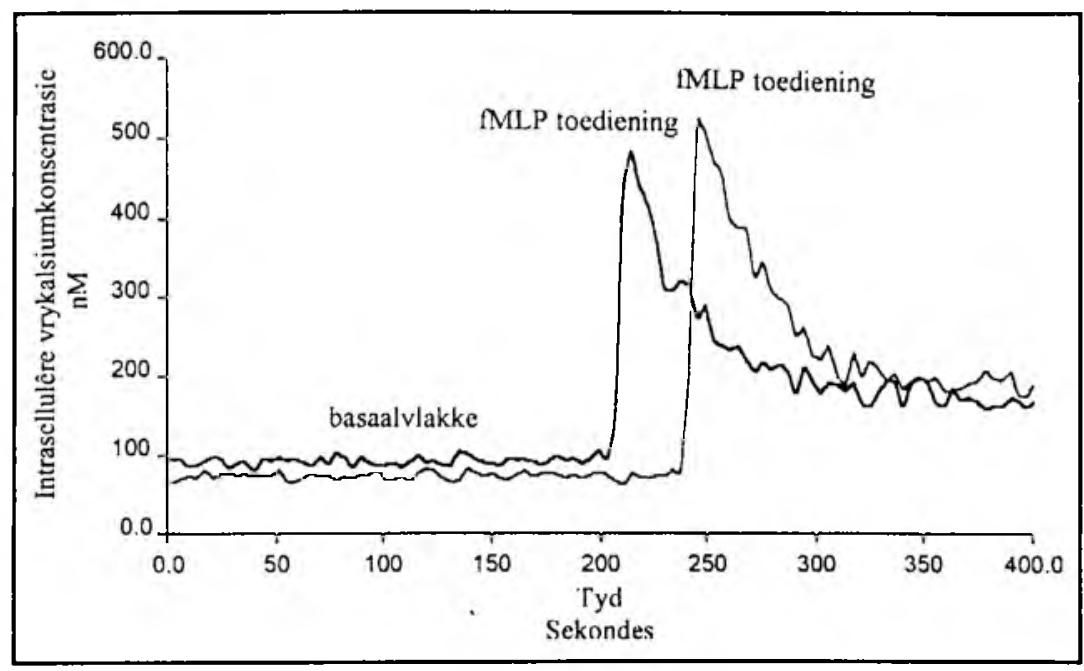

FIGUUR 8

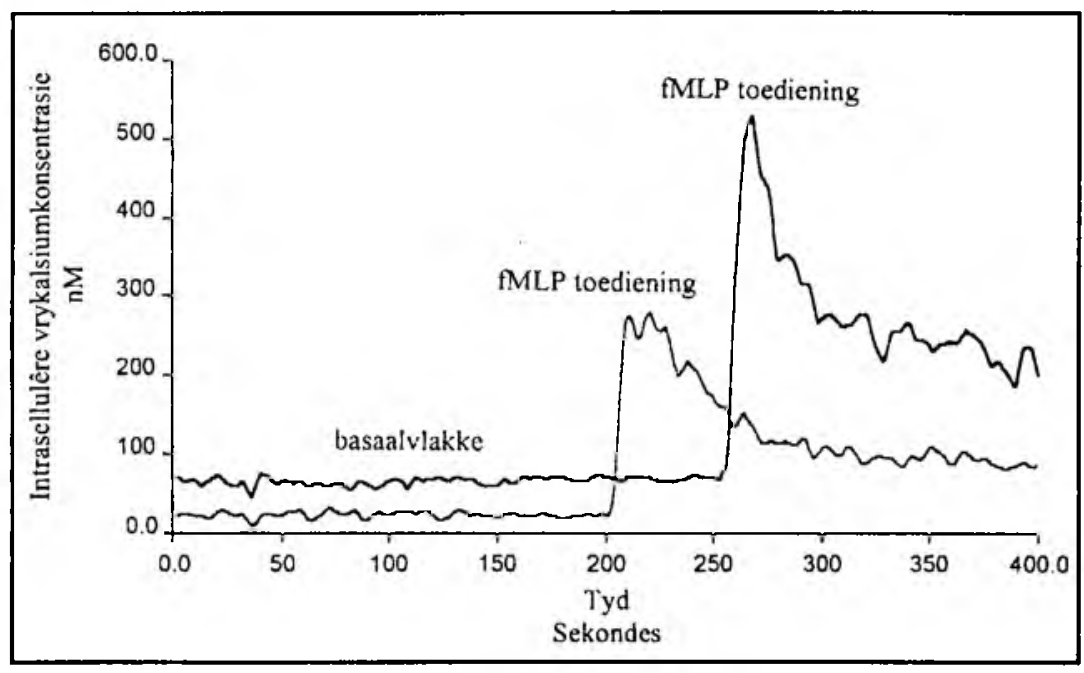

FIGUUR 9

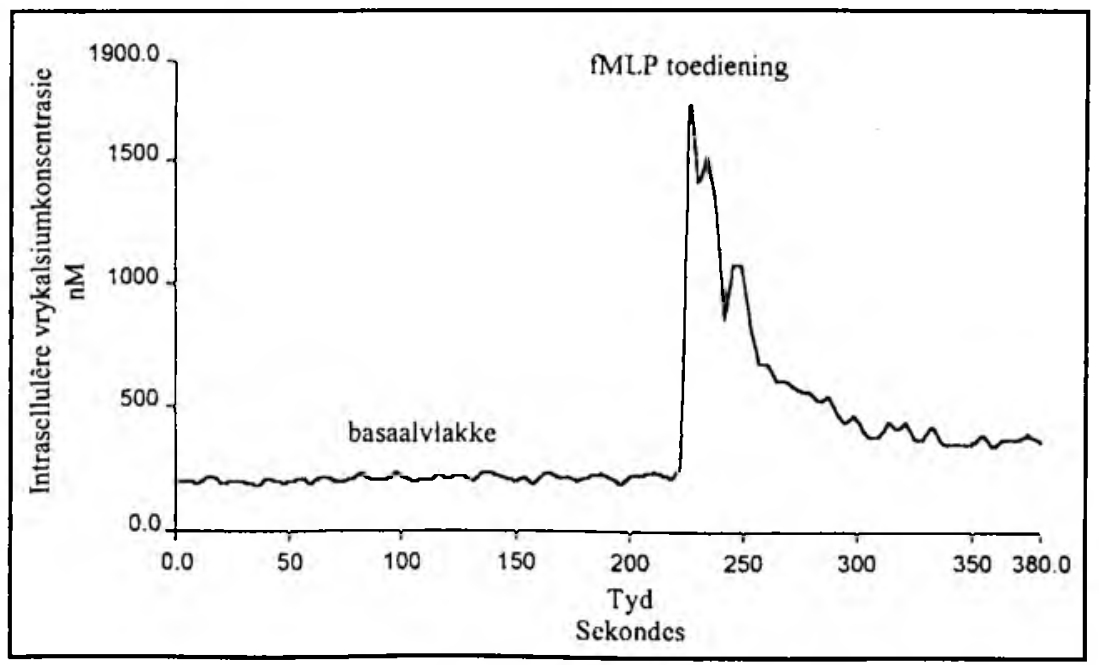




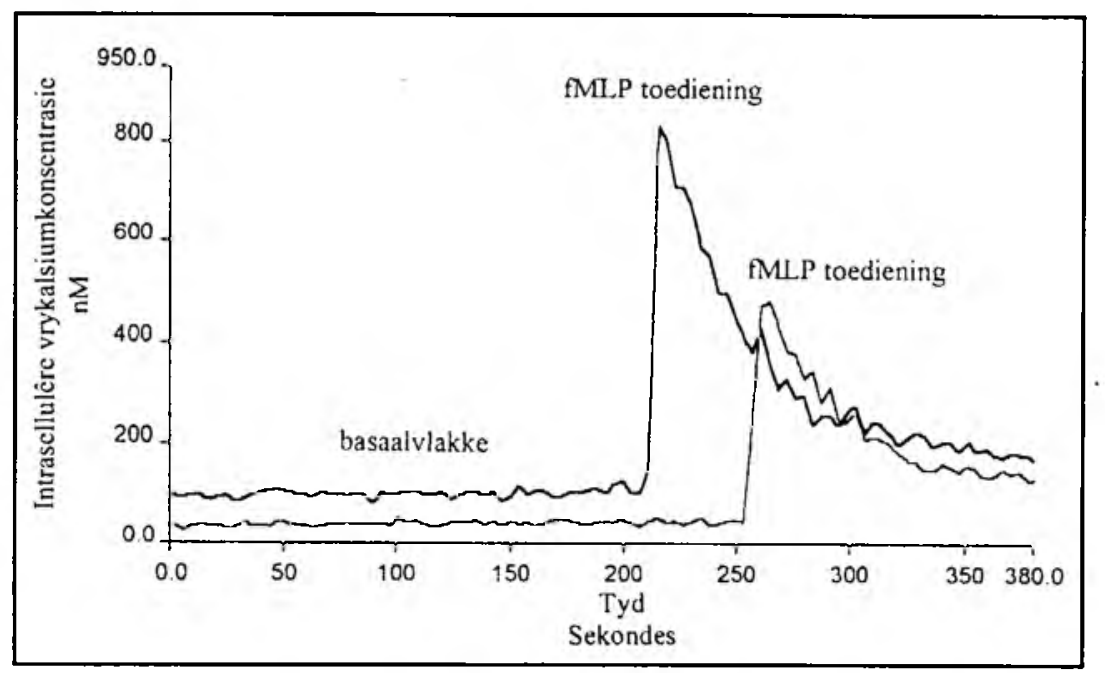

FIGUUR II

\section{BESPREKING}

Dic uitlek van fluoressente kalsiumindikators na die ckstrasellulêre medium kan dic bepaling van dic konsentrasies van intrasellulêre vry kalsium in selle komplisecr. Dit is veral 'n probleem met dic bepaling van dic konsentrasies van intrasellulêre vry kalsium in 'n spektrofluorometerkuvet wanneer van media met 'n fisiologiese kalsiumkonsentrasie gebruik gemaak word. ${ }^{2}$ In 'n spektrofluorometerkuvet word dic fluoressensicbepalings verkry van alle indikatormolekules, hetsy in die ekstrasellulêre medium of in die sitoplasma. Indien daar dus nocmenswaardige uitlek van die kalsiumindikator na dic ekstrasellulêre medium plaasgevind het, sal dic indikators in die ckstrascllulêre medium lei tot die bepaling van 'n verhoogde konsentrasie van die intrasellulêre vry kalsium a.g.v. die fisiologiese kalsiumkonsentrasic in die ekstrasellulêre medium. Dit is bekend dat die fluoressente kalsiumindikator fura- 2 mag uitlek na die ekstrasellulêre medium en dus aanleiding kan gee tot die meet van 'n verhoogde konsentrasie van dic intrasellulêre vry kalsium. Fura-PE3, 'n indikator verwant aan fura-2, is ontwikkel in 'n poging om uitlekking te verminder en word ook as sulks deur die patenthouers voorgchou. ${ }^{3}$ Uit dic resultate van hierdic studic is daar geen noemenswaardige verskil gevind tussen dic mate van uitlek vir fura-2 en fura-PE3 nic - veral nic met ' $n$ verlengde inkubasieperiode nie. In normale roctineanalises verteenwoordig die verlengde inkubasieperiode dic tyd wat dit sou neem indien meer as een monster op 'n keer gedoen word. Die prakticse implikasies van die resultate is dat dic bepalings nog steeds, so gou moontlik ná dic laai en wasstappe gedoen moct word. Dic bepaling van intrascllulêre vry kalsium van mecr as cen bloedmonster per keer word dus uitgeskakel. Fura-PE3 bied hier dus gecn voordecl bo fura-2 nic, in teenstelling met dit wat deur dic patenthouers voorgehou word. Dit is egter nodig om te benadruk dat die resultate slegs van toepassing is vir neutroficle, siende dat verskillende seltipes variecr in hul vermoë om dic kalsiumindikators te hanteer. Wat betref die geskiktheid van beide fura-2 en fura-PE3 vir dic bepaling van intrasellulêre vry kalsium: beide dic indikators lek na dic ekstrascllulêre medium, maar indien dic inkubasictye so kort as moontlik en konstant gehou word vir verskillende monsters is die tegniek aanvaarbaar. Die uitlek na dic ekstrasellulêre medium sal natuurlik eksperimente met 'n lang tydsverloop kompliseer. Die waardes wat verkry is op normale gesonde persone wys dat die herhaalbaarheid goed is. Die vraag of die metode wel sensitief genocg is om variasies aan te toon, het vervolgens ontstaan. Bepaling van intrasellulêre vry kalsium in intensiewesorgpasiënte het getoon dat die metode wel variasies kan aandui. Alhoewel nie hier getoon nie omdat nog nie genoeg resultate verkry is nic, wil dit voorkom asof 'n drastiesc verhoging in intrasellulêre vry kalsium sonder terugkecr na normaal gepaardgaan met 'n swak prognose.

Samevattend kan gesê word dat dic bepaling van intrasellulêre vry kalsium in neutroficle met fura-PE3 geen werklike voordele inhou bo fura-2 nie, dat dic herhaalbaarheid van dic bepaling van intrascllulêre vry kalsium deur beide die fluoressente kalsiumindikators aanvaarbaar is indien dic tydsverloop tussen die laai en wasstappe en die begin van die fluoressensiebepalings kort gehou word deur slegs een monster op 'n slag te doen, en dat die metode sensitief genoeg blyk te wees om variasie in intrasellulêre vry kalsium waar te neem.

Befondsing: NRF fonds, MC Kruger; Navkom 1999 AM Koorts

\section{LITERATUURVERWYSINGS}

1. Rink, T.J. (1988). Measurement of Cytosolic Calcium: Fluoresent Calcium Indicators, Mineral and Electrolyte Metabolism, 14, 7-14.

2. Thomas, A.P., Delaville, F. (1991). The Use of Fluorescent Indicators for Measurement of Cytosolic-Frec Calcium Concentration in Cell Populations and Single Cells. In Cellular Calcium: A Practical Approach, McCormack, J.G., Cobbold, P.H. cds. (Oxford Unversity Press, New York) p. 1-54.

3. Vorndran, C., Minta, ., Poenie, M. (1995). New Iluorescent Calcium Indicators Designed for Cytosolic Retention or Measuring Calcium near Membranes, Biophysical Journal, 69, 2112-2124.

4. Waddcll, T.K., Fialkow, L., Chan C.K., Kishimoto, T.K., Downey, G.P. (1994). Potentiation of the Oxidative Burst of Human Ncutrophils, The Journal of Biological Chemistry, 269(28), 1848518491.

5. Collison, K.S., Kwaasi, A.A.^., Parhar, R.S., Al-Sedairy, S.T., AlMohanna, I.A.A. (1995). Monomeric Human IgE Evokes a Transicnt Calcium Risc in Individual Human Ncutrophils, Journal of Leukocyte Biology, 58, 459-467.

6. Theler, J.M., Lew, D.P., Jaconi, M.E., Krause, K-H., Wollhcim, C.B., Schlcgcl, W. (1995). Intracellular Pattern of Cytosolic Ca2+ Changes During Adhesion and Multiple Phagocytosis in Human Neutrophils. Dynamics of Intraccllular $\mathrm{Ca}^{2+}$ Stores, Blood, 85(8), 2194-2201.

7. Böyum, A. (1968). Isolation of Mononuclear Cells and Granulocytcs from Human Blood, Scandinavian Journal of Clinical and Laboratory Investigation - Supplement, 97, 77-89.

8. Grynkicwicz, G., Pocnic, M., Tsien, R.Y. (1985). A New Gencration of $\mathrm{Ca}^{3 *}$ Indicators with Greatly Improved Fluorescence Propcrtics, The Journal of Biological Chemistry, 260(6), 3440-3450. 